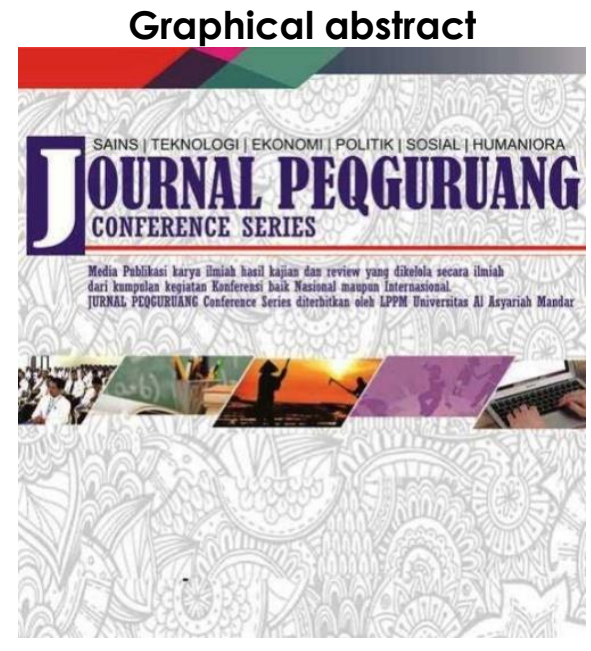

\title{
PENERAPAN NEW PUBLIK MANAJEMEN DALAM MEWUJUDKAN GOOD GOVERNANCE DI KANTOR KECAMATAN KABUPATEN MAMASA
}

${ }^{1}$ Vingki Nela*, ${ }^{2} \mathrm{Abdul}$ Latief, ${ }^{3}$ Kamaruddin Tone

Fakultas Keguruan dan Ilmu Pendidikan, Program Studi Pendidikan Kewarganegaraan, Universitas Al Asyariah Mandar

Coresponding author vingkii009@gmail.com

\begin{abstract}
The purpose of this research is to find out how the application of new public managemen in the Tabulahan sub-districh office. This reseach is a type of qualitattive reseach. Data collection techniques namely the interview method and the observation method. The results show that the application of the new public managemen in reaziling good governance can be consideredquite affective can be sen from the reseach conducted by the interview and obsevation process. There are still some obstacles in the application of the principle of new public management, this is due to lack of human resouces, availability of office facilities and community behavior.
\end{abstract}

Keywords: The Application Of New Public Management, Good Governance

\begin{abstract}
Abstrak
Tujuan dari penelitian ini adalah Untuk mengetahui bagaimana penerapan New Publik Manajemen di Kantor Kecamatan Tabulahan. Penelitian ini merupakan jenis penelitian Kualitatif. Teknik pengumpulan data yaitu dengan metode wawancara dan metode observasi. Hasil penelitian menunjukkan Penerapan New publik manajemen dalam mewujudkan Good Governance di kantor kecamatan tabulahan, dapat dinilai cukup efektif dapat dilihat dari penelitian yang dilakukan dengan proses wawancara dan observasi. Masih terdapat beberapa kendala dalam penerapan prinsip New publik manajemen, ini disebabkan karena kurangnya sumber daya manusia, ketersediaan fasilitas perkantoran, serta prilaku masyarakat.
\end{abstract}

Kata Kunci: Penerapan New Publik Manajemen, Good Governance

\section{Article history}

DOI: http://dx.doi.org/10.35329/ip.v2i2.1135

Received : 25 Agustus 2020 | Received in revised form : 17 September 2020 | Accepted : 01 Oktober 2020 


\section{PENDAHULUAN}

Berawal pada tahun 1991 oleh Christoper

Hood. Sebagai reaksi terhadap tidak memadainya model Administrasi Publik Tradisional, pendekatan manajemen modern di sektor publik yang pada awalnya muncul di eropa tahun 1980- 1990. Tetapi secara umum konsep New Publik Manajemen berawal dari ide Christopher Hood sebagai awal mula paradigma alternatif. New Publik Manajemen di Indonesia sebenarnya sudah dimulai terhadap akuntabilitas Kinerja Instansi Pemerintah pada tahun 1999 sejak dikeluarkannya Intruksi Presiden Nomor 7 Tahun 1999. Wujud dari pelaksanakan Akuntabilitas Kinerja Instansi Pemerintah yaitu pertanggungjawaban instansi pemerintah dalam mencapai misi dan tujuan organisasi dalam pelaksanaan tugas- tugas pemerintah.

Pelaksanaan New Publik Manajemen pada organisasi pemerintahan di Indonesia sampai saat ini masih menunjukkan perkembangan yang positif, yang sangat berpengaruh terhadap peningkatan kinerja pemerintah. Menurut Oktavianus (2020), nilai motivasi pelayanan publik meruapakan komitmen terhadap kepentingan publik; empati; dan pengorbanan diri yang nilainya relatif tinggi.

Penelitian yang berhubungan dengan penerapan New Publik Manajemen sudah banyak dilakukan yang ada di Indonesia, yaitu Mohammad Akbar pada tahun (2015), melakukan penelitian mengenai Penerapan prinsip- prinsip New Publik Manajemen dan Governance dalam Revormasi Administrasi. Hasil dari penelitian ini bisa disimpulkan bahwa dengan adanya perubahan paradigma pemerintah menuju kearah birokrasi yang ideal, yang didukung aparatur pemerintah yang menunjang tinggi nilai- nilai dan perilaku positif, juga adanya komunikasi yang baik diantara pemerintah dan masyarakat, dan ikut berperan didalamnya, maka Good Governance dapat diwujudkan.

New Publik Manajemen untuk masa sekarang ini masih menjadi persoalan yang perlu memperoleh perhatian dan penyelesaian yang komerhensif, hal ini dibuktikan ketika timbul berbagai tuntutan pelayanan publik sebagai tanda ketidakpuasan masyarakat. Harus diakui bahwa pelayanan yang diberikan oleh pemerintah kepada masyarakat mengalami pembaharuan baik dari sisi paradigma maupun dari format pelayanan seiring dengan meningkatnya tuntutan masyarakat dan tuntutan didalam pemerintah itu sendiri. Meskipun demikian, perubahan yang dilihat dari sisi belumlah memasukkan bahkan masyarakat masih diposisikan sebagai pihak yang tidak berdaya. Kecendrungan seperti ini terjadi karena masyarakat masih diposisikan sebagai pihak yang melayani bukan dilayani.

Undang- Undang nomor 25 Tahun 2009 pada Bab 1 Pasal 1 Ayat 1 tentang pelayanan publik, yang dimaksud dengan pelayanan publik adalah kegiatan atau rangkaian kegiatan dalam rangka pemenuhan kebutuhan pelayanan sesuai dengan peraturan perundang-undangan bagi setiap warga negara dan penduduk atas barang, jasa dan atau pelayanan administratif yang disediakan oleh penyelenggara pelayanan publik. Pemerintah berkewajiban melayani masyarakat yang meminta layanan dengan memberikan kemudahan tanpa mempersulit prosedur/aturan.

Penelitian ini dianggap perlu karena berupaya menggambarkan perilaku pemerintah dalam upaya peningkatan kualitas layanan kepada masyarakat. Melalui penelitian ini, diharapkan dapat menemukan sebuah solusi dalam perbaikan kualitas pelayanan melalui perubahan paradigma perilaku pemerintah, berdasarkan hal tersebut maka dilakukanlah penelitian dengan judul Penerapan New Publik Manajemen Dalam Mewujudkan Good Governance di Kecamatan Tabulahan Kabupaten Mamasa.

\section{METODE PENELITIAN}

\section{a. JENIS PENELITIAN}

Jenis penelitian yang digunakan dalam penelitian ini adalah penelitian Kualitatif. Pendekatan yang digunakan dalam penelitian ini adalah pendekatan naturalistik yang berarti Penelitian hanya dapat dilaksanakan dengan kondisi alamiahnya; Data- data yang dikumpulkan adalah berdasarkan perspektif yang diteliti; Model penelitiannya bersifat fleksibel karena berdasarkan prinsip reflexive; Tidak ada standar atau alat, metode observasi, maupun cara menganalisis.

\section{b. LOKASI DAN WAKTU PENELITIAN}

Penelitian ini dilakukan dengan mengambil lokasi peneltian di Kantor Kecamatan Tabulahan Kabupaten Mamasa, mulai bulan april 2020 sampai bulan mei 2020.

\section{c. SUBJEK PENELITIAN}

Subjek dari penelitian ini adalah seluruh Aparat di Kantor Kecamatan Tabulahan sebanyak 19 orang dan seluruh warga masyarakata yang mendapat pelayanan di Kantor Kecamatan Tabulahan Kabupaten Mamasa.

\section{d. TEKNIK PENGUMPULAN DATA}

Teknik pengumpulan data yang digunakan dalam penelitian ini ada 2 yaitu:

1. Metode Wawancara, teknik wawancara secara umum seringkali digunakan oleh peneliti yang menggunakan metode penelitian kualitatif. Interview dapat digunakan untuk mengumpulakn informasi yang tidak mungkin diperoleh lewat observasi. 
Teknik interview ini paling tepat digunakan pada saat peneliti ingin mengetahui secara lebih objektif dan terlibat secara langsung mengenai bagaimana penerapan New Publik Manajement.

2. Metode Observasi, yaitu data yang dibutuhkan diperoleh dengan melakukan pengamatan langsung terhadap fenomena dan noumena yang relevan dengan fokus penelitian. Penekanan observasi lebih pada upaya mengungkap makna- makna yang terkandung dari berbagai aktifitas terarah tujuan.

\section{e. INSTRUMEN PENELITIAN}

Instrumen penelitian yang digunakan dalam penelitian ini adalah peneliti sendiri. Berkaitan dengan dijadikannya manusia sebagai instrumen utama dalam proses penelitian, bahwa hanya manusia yang memiliki beberapa kemampuan dalam proses instrumen penelitian yaitu:

1. Kepekaan untuk berintegrasi dengan lingkungannya,

2. Kemampuan beradaptasi dengan situasi dan kondisi lingkungan penelitiannya,

3. Kemampuan menangkap segala sesuatu yang utuh dan menyeluruh,

4. Kemampuan memproses data dengan cepat,

5. Kemampuan untuk mengembangkan dan mengggunakan kesimpulan penelitiannya, misalnya untuk memahami latar social,

6. Kemampuan untuk meringkas data, melakukan klasifikasi, dan koreksi data,

7. Kesempatan dan kemampuan untuk mengeksplorasi respon- respon atau unik untuk memperoleh pemahaman yang lebih mendalam

\section{f. TEKNIK ANALISIS DATA}

Teknik pengumpulan data yang digunakan dalam penelitian ini meliputi 3 alur kegiatan yaitu:

1. Reduksi Data, yaitu data yang telah dikumpulkan direduksi dengan melakukan penyederhanaan pengabstrakan, pemilahan dan pemetaan (persamaan dan perbedaan) sesuai dengan fokus penelitian secara sistematis dan integral. Reduksi data ini berlangsung hingga sampai pada penarikan kesimpulan.

2. Penyajian Data, yaitu data dalam penelitian ini disusun secara naratif, bentuk label dan gambar, yang dibuat setelah pengumpulan data dan reduksi data dengan didasarkan pada kontek dan teori yang telah dibangun untuk mengungkapkan fonomena dan noumena yang terjadi sesuai dengan fokus penelitian.

3. Penerikan Kesimpulan, yaitu dalam proses ini selalu disertai dengan upaya verifikasi (pemikiran kembali), sehingga ditemukan ketidak sesuaian antara fenomena, noumena, data, dengan konsep dan teori yang dibangun, maka peneliti kembali melakukan pengumpulan data, atau reduksi data atau perbaikan dalam penyajian data kembali, sehingga dapat diperoleh kesimpulan peneliti menggunakan kerangka teori yang dipakai sebagai kerangka pikir penelitian.

\section{HASIL DAN PEMBAHASAN}

\section{PENERAPAN NEW PUBLIK MANAJEMEN DI KANTOR KECAMATAN TABULAHAN:}

Hasil penelitian menunjukkan Penerapan New publik manajemen dalam mewujudkan Good Governance di kantor kecamatan tabulahan, dapat dinilai cukup efektif dapat dilihat dari penelitian yang dilakukan dengan proses wawancara dan observasi. Dari 10 prinsip New Publik Manajemen hanya 5 yang terlihat penerapannya di Kantor Kecamatan Tabulahan, yaitu:

1. Pemerintah yang katalis, artinya pemerintah lebih banyak memberikan tanggung jawab kepada masyarakat untuk menyelenggarakan urusannya. Pemerintah hendaknya lebih diarahkan sebagai pengatur dan pengendali dari pada sebegai pelaksana langsung.

Menurut hasil wawancara dengan seorang tokoh masyarakat, beliau mengatakan bahwa:

"penerapan prinsip ini sudah dilakukan oleh pemerintah, namun pelaksanaannya belum optimal namun pemerintah sudah berusaha untuk memaksimalkan prinsip tersebut"

Dengan kata yang sama juga dikeluarkan oleh seorang aparat kecamatan tabulahan, beliau mengatakan bahwa:

"pemerintah sudah berusaha semaksimal mungkin untuk penerapan prinsip ini agar pelaksanaanya lebih optimal"

2. Pemerintah milik masyarakat, artinya bahwa pemerintah mestinya mendorong agar kontrol atas pelayanan diberikan kepada masyarakat, prinsip ini juga dapat memberdayakan masyarakat untuk mampu melakukan usaha dan mengurangi ketergantungan kepada pemerintah.

Dilihat dari wawancara kepada informan toko masyarakat, beliau mengatakan:

"penerapan prinsip ini sudah dilakukan oleh pemerintah kecamatan tabulahan dengan baik namun belum efektif"

Dikatakan baik karena pemerintah kecamatan tabulahan terus berupaya untuk memberikan dan melaksanakan tugasnya kepada masyarakat. Dengan demikian, kualitas pelayanan yang diharapkan masyarakat tidak mustahil untuk diwujudkan.

Dari hasil wawancara kepada informan pemerintah kecamatan tabulahan bapak Usman selaku camat tabulahan, beliau mengatakan: 
"kendala yang dialami pemerintah kecamatan dalam penerapan prinsip ini yaitu kurangnya partisiasi masyarakat, dari kami sebagai pihak pemerintah sudah diterapkan, namun persepsi masyarakat masih belum maksimal"

3. Pemerintah yang digerakkan oleh misi, artinya pemerintah dapat bekerja secara lebih efisien dan efektif dibanding pemerintah yang hanya digerekkan oleh peraturan semata. Dampak positifnya yaitu mendatangkan hasil yang lebih baik dan memiliki semangati yang tinggi.

Dari hasil wawancara langsung dengan informan tokoh masyarakat Diana, beliau mengatakan:

"peneraan ini sudah dilaksanakan namun belum sepenuhnya optimal, pemerintah dikecamatan belum melaksanakan dengan baik apa yang kami harapkan. Penerapan dari prinsip ini belum bisa dikatakan efektif dan efisien"

Penerapan prinsip ini dapat optimal apabila pemerintah memiliki kemampuan untuk mengidentifikasi kebutuhan masyarakat, menyusun prioritas kebutuhann dan mempunyai daya tanggap yang cepat agar penyelenggaraannya dapat terlaksana dengan baik.

Dari hasil wawancara langsung dengan informan Kepala Sub Bagian Keegawaian, beliau mengatakan:

"secara keseluruhan penerapan prinsip ini belum sepenuhnya maksimal sehingga dapat dikatakan rendah, namun kami akan berusaha untuk dapat mencapai titik maksimal, berhubung penerapan new publik manajemen dikantor kecamatan tabulahan ini baru kami terapkan".

Ini berarti secara keseluruhan prinsip yang diterapkan masih belum konsisten untuk dilaksanakan dan belum sepenuhnya maksimal atau belum optimal, sehingga dapat dikatakan masih rendah.

4. Membiayai hasil, artinya pemerintah hanya berfokus pada pencapaian kinerja yang lebih baik, dalam hal ini prosedur kerja yang berbelit- belit harus dihilangkan.

Dari hasil wawancara kepada informan aparat pemerintah Bapak Camat Kecamatan Tabulahan, beliau mengatakan:

"selaku Camat kami selalu berpartisiasi dalam menyelenggarakan pemerintah kami dituntut untuk selalu melakukan tugas dan tanggung jawab kami dengan baik"

Dengan kata yang sama dikeluarkan oleh Bapak Sekertaris kecamatan tabulahan, beliau mengatakan: "pelaksanaan maupun imlementasi prinsip ini telah terselenggara dengan baik serta melibatkan masyarakat dalam implementasinya"

Ini berarti bahwa secara keseluruhan prinsip ini yaitu membiayai hasil yang ditunjukkan dalam pelayanan public telah diterapkan.

5. Pemerintahan yang mencegah masalah, artinya pemerintah harus menyusun persiapan pencegahan bencana seperti kebakaran, banjir, dan bencana alam lainnya.

Dari hasil wawancara dengan seorang aparat kantor kecamatan mengatakan bahwa:

"untuk prinsip ini kami sudah laksanakan dan kami akan lebih meningkatkan pelaksanaannya”

Kemudian tanggapan dari seorang tokoh masyarakat, beliau mengatakan bahwa: "penerapan prinsip ini sudah baik dan harus dipertahannkan oleh pemerintah"

\section{FAKTOR YANG MENDUKUNG PENERAPAN NEW PUBLIK MANAJEMEN}

\section{SUMBER DAYA MANUSIA}

Sumber daya manusia adalah suatu keahlian atau kemampuan yang dimiliki pemerintah yang bertugas dalam melaksanakan tugasnya, seperti pengetahuan dan ketrampilan komputer, mengetahui semua data- data dan melakukan pengecekan data yang ada. Untuk lebih meningkatkan keberadaan sumber daya manusia aparat harus menjadi lebih berkualitas dan trampil, perlu diberi peningkatan pengetahuan dan ketrampilan melalui diklat- diklat keterampilan.

\section{SARANA DAN PRASARANA}

Sarana dan prasarana adalah ketersediaan peralatan dan perlengkaan kerja yang menunjang pekerjaan berupa ketersediaan sarana komputer, ketersediaan ruang pengelolaan data dan ketersediaan perlengkaan/peralatan kerja.

\section{PERILAKU MASYARAKAT}

Perilaku masyarakat adalah tindakan yang dilakukan oleh masyarakat yang tercermin dalam kegiatan baik sadar maupun tidak sadar dapat mempengaruhi pelayanan. Perilaku masyarakat yang dimaksud yaitu sesuai dengan prosedur, memberikan suatu bentuk imbalan dan memberikan layanan sesuai dengan urutan- urutan prosedur yang telah ditetapkan. 


\section{SIMPULAN}

Berdasarkan hasil penelitian dan pembahasan mengenai "Penerapan New Publik Manajement Dalam Mewujudkan Good Governance di Kantor Kecamatan Tabulahan Kabupaten Mamasa" maka dapat disimpulkan bahwa:

a. Keterbukaan informasi pemerintah kecamatan tabulahan dalam penyelenngaraan program pembangunan sudah baik, karena upaya kecamatan dalam memberikan keterbukaan informasi. Tetapi dalam memberikan keterbukaan dalam memberikan informasi masih belum optimal. Walaupun ada bebarapa warga menurut hasil wawancara mengatakan kecamatan tabulahan masih belum efektif dan optimal karena New Publik Manajement ini merupakan penyelenggaraan pemerintah berdaya tangga cepat, namun temuan pada penelitian di dapati penyelenggaraan pemerintahan kecamatan tabulahan masih lamban.

b. Factor- factor yang mendukung Penerapan New Publik Manajement ditentukan oleh sumber daya manusia, sarana dan prasarana serta prilaku masyarakat. Ketiga factor ini masih perlu diperbaiki berkaitan dengan tingkat pengetahuan dan ketrampilan komputer dalam pengoprasian akses data sesuai dengan keberadaan fasilitas perkantoran yang disediakan. Keterlambatan dari kebanyakan proses ini perlu diberikan penyadaran dan penyuluhan kepada masyarakat untuk mengembangkan prilaku yang sesuai dengan prosedur pelayanan public.

\section{DAFTAR PUSTAKA}

Heryanto Yanto, 2014. Implementasi Good Governance Terhadap peningkatan pelayanan publik di Indonesia. Universitas Swadaya Gunung Jati.

United Nations Development Program (UNDP), 2016. Mewujudkan Good Governance Melalui Pelayanan Publik. Politeknik Kridatama, Bandung.

Alamsyah Anggriani, 2016. Perkemabangan Paradigma Administrasi Publik. Universitas Islam Negeri Makassar, Makassar.

Nur Sayidah, 2015. Implementasi Konsep New Publik Manajemen Di Dinas Koperasi Dan UKM Kota Surabaya. Fakultas Ekonomi Universitas Dr. Soetomo, Surabaya.

Dr. Taufiqorokhman, A.ks., M.Si dan Dr. Evi Satispi, SP.M.Si, 2018. Teori dan Perkembangan Manajemen Pelayanan Publik. Jln. KH. Ahmad Dahlan, Cirendeu, Ciputat, Tangerang Selatan.
M. Rizki Pratama, 2013. Paradigma Baru Manajemen Pelayanan Publik: Memberi Nilai Tambah (Adding Value) Pelayanan Publik Bagi Masyarakat di Daerah. Universitas Airlangga, Surabaya.

Nurwino Wajib, 2016. Pentingnya Penjaminan Kualitas Pelayanan Publik. Medan: Direktorat Jendral Cipta Karya.

Oktovianus, O., \& Saharuddin, A. D. (2021). Tipologi Nilai-Nilai Motivasi Pelayanan Publik Di Pdam Kabupaten Mamasa. Mitzal (Demokrasi, Komunikasi dan Budaya): Jurnal Ilmu Pemerintahan dan Ilmu Komunikasi, 5(1). 